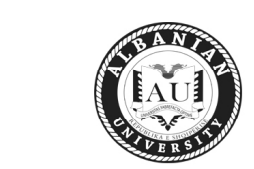

Viti i XII' ${ }^{\text {të }}$ i Botimit, Nr.1-2,

Dhjetor 2020

\title{
HERBALIZMI DENTAR
}

\section{Xhuena Amuli*, Valbona Disha*}

*Departamenti i Stomatologjisë, Fakulteti i Shkencave Mjekësore, Albanian University, Tiranë, Shqipëri.

Adresë kontakti : xhoena_a@hotmail.com

\section{Përmbledhje}

Kurimi i patologjive të ndryshme shëndetësore nëpërmjet bimëve tashmë njihet në të gjithë botën. Janë të njohura efektet e tyre antimikrobiale, antifungal, antivirale etj., veti këto që mund të shfrytëzohen për të trajtuar patologji edhe në kavitetin oral. Nga ana tjetër, kur krahasohen me medikamentet, bimët janë më të sigurta në përdorim dhe më me pak efekte anësore.

Qëllimi. Si ndikon në reduktimin e pllakës dentare dhe kariesin dentar përdorimi i disa bimëve (kanellës, stivias, propolisit dhe lëkurës së portokallit).

Materiale dhe metoda. Ky studim është një rishikim literature, në vetvete kualitativ, duke qenë se është bazuar në literaturë ekzistuese. Duke përdorur fjalët kyçe për kërkimin e artikujve në lidhje me temën, u shfaqën rreth 500 artikuj. Nga këto u zgjodhën 8 artikuj që u shfrytëzuan për qëllimin e studimit. Artikujt e përzgjedhur përfshinin studime në lidhje me bimët e interesit dhe me efektet që ato kanë në pllakë dhe inhibimin e evolucionit të kariesit. Artikujt i përkasin viteve të fundit dhe trajtojnë studime in vivo/in vitro që janë kryer duke përdorur bimët e interesit.

Rezultate. Aprovimi i potencialeve në frenimin e aktivitetit mikrobial dhe reduktimin e akumulimit të pllakës patogjene në kavitetin oral, janë disa nga rezultatet e këtij studimi. Interesant është fakti që studiues të ndryshëm kanë nxjerrë rezultate të përafërta me njëri tjetrin lidhur me vetitë pozitive të bimëve të interesit.

Konkluzione. Është i padiskutueshëm fakti që bimët kanë pranueshmëri më të mirë nga ana e pacientit dhe më pak efekte anësore. Studimet e kryera kanë lënë rrugë të hapur drejt mundësive të përfshirjes së bimëve të interesit në produktet e higjenës orale. Mungesa e standardizmit të kësaj disipline dhe e një instituti kërkimor përbën kufizim për këtë punë kërkimore.

Fjalë çelës: Herbalizmi, mjekësia bimore, karies, pllakë patogjene. 
HERBALIZMI DENTAR

\section{DENTAL HERBALISM}

\section{Abstract}

It is a well know that we can treat different health conditions using medicinal herbs. The properties of herbs such as antimicrobial, antioxidant, antifungal, antiviral etc., are alreday proved and can be utilized in the treatment of different pathologies concerning the oral cavity also. On the other hand, if we compare herbs to medicaments, the first ones are safer in use, due to the reduced number of side effects.

The aim. What is the effect of some herbs (cinnamon, stevia, propolis and orange peel) in the bacterial plaque and caries.

Materials and methods. This article is a literature review. Around 500 articles were shown during the search using the keywords. Only 9 articles were selected and used for the purpose of this article. The articles include various studies concerning the herbs of interest, their effects on the dental plaque and to the dental caries evolution. The articles are newly published and adress in vivo and in vitro researches using the herbs of interest.

Results. The approval of the inhibiting potentials towards the bacterial activity and dental plaque formation are some of the results. The fact that different authors had similar results is interesting.

Conclusions. It is undisputable that herbs are easily accepted and have a reduced number of side effects. The conducted studies have already led the way towards a future with complete herbal based oral products. The lack of standardisation of this discipline and the absence of a research institute in Albania causes limitations in this research work.

Keywords: Herbalism, herbal medicine, caries, pathogenic plaque.

\section{HYRJE}

Bimët e përdorura për trajtimin e problemeve të ndryshme shëndetësore kanë ekzistuar për vite me rrallë, madje edhe para se shkenca të hidhte hapat e saj të parë në zbulimin dhe njohjen e tyre. Ne jetojme mes bimëve, disa i konsumojmë në përditshmërinë tonë dhe tek disa të tjera jemi mbështetur për përdorimin e tyre farmaceutik. Madje për një kohë të gjatë bimët kanë qenë e vetmja alternativë mjekuese për mjekët. OBSH (1) nxorri rezultatet se rreth $80 \%$ e popullatës botërore akoma varet nga bimët mjekësore për trajtimin e 
Xhuena Amuli, Valbona Disha

sëmundjeve të ndryshme, kjo falë aksesit të shpejtë, kostos ekonomike më të ulët dhe shfaqjes së më pak efekteve anësore. Terapia me bimë mjekësore është më e pranueshme nga pacientët për shkak të popullaritetit që ajo ka.

Së pari le të kujtojmë se çfarë është Mjekësia Bimore apo Herbalizmi siç njihet në termat e saj modern. Herbalizmi (2) është shkenca që merret me studimin e botanikës dhe indikimet e bimëve mjekësore në shërimin e gjendjeve patologjike të ndryshme. Bazat e farmakologjisë së sotshme janë bimët. Drogërat e kohëve të sotshme sintetizohen në laboratore, standardizohen, dozohen dhe nuk përmbajnë më shumë se një lëndë përbërëse duke kufizuar kështu efektet e tyre në lidhje me patologjinë për të cilën ato merren dhe duke rritur efektet anësore. Çmimet e tyre janë të papërballueshme për shumë familje. Në krahun tjetër bimët ofrojnë një zgjidhje natyrale. Secila prej tyre konsiston në një përzierje të larmishme, jo me një por disa përbërës të cilët kanë një veprim sinergjik duke ndihmuar në ndryshimin për mirë dhe ribalancim të gjendjes së trupit.Kjo mënyrë e administrimit të disa barnave në një përzierje të vetme e cila ofrohet nga bimët do të rezultojë në nivele më të ulëta të akumulimit të rezistencës mikrobiale nëse flasim për rastin e antibiotikëve. Ndryshe nga administrimi i lëndëve farmacetuike me një lëndë përbërëse, ku po dalin jashtë lojë shumë antibiotikë të cilët nuk po japin më veprimet e dëshiruara pikërisht për shkak problemit të reziş tencës mikrobiale. Në anën tjetër nuk duhet të harrojmë mungesën e standardizimit të bimëve mjekësore. Kjo përbën një pikë të dobët të tyre.

\section{METODA DHE MATERIALE}

Për realizimin e këtij punimi u bë kërkim elektronik (duke përfshirë këtu google, pubmed) për artikujt e publikuar në periudhën kohore 26 Dhjetor 2015 deri më 30 Korrik 2019. Artikujt e përdorur analizojnë tema në lidhje me studime in vivo dhe in vitro. Në fund $u$ përzgjodhën ato pjesë që përmbushnin interesat e studimit tonë. Është përdorur kjo metodë kërkimore pasi kjo fushë nuk ka të dhëna të mjaftueshme në gjuhën shqipe dhe kërkimi mae nual nuk ishte efikas për këtë studim. Gjithashtu një pjesë e mirë e të dhënave bazohet në librin “DENTAL HERBALISM, NATURAL THERAPIES FOR THE MOUTH” nga Leslie M.Alexander dhe Linda A.Straub-Bruce (viti i publikimit 2014).

Në literaturën ku është bazuar ky studim paraqiten rreth 40 bimë, nga te cilat u zgjodhën vetëm prej tyre.

- Kanella

- Stivia 
HERBALIZMI DENTAR

- Propolisi

- Lëkura e portokallit

Karakteristikat e bimëve të marra për bazë në studim janë si më poshtë.

A. KANELLA (2)

1.Emri i përbashkët: Casiia, kanella e vërtetë

2.Emri botanik: Cinnamomun cassia

3.Familja e bimës: Lauraceae

4.Pjesa e përdorur: Pjesa e brendshme e bishtit dhe shkopinjtë

5.Gjendja e përdorur: E thatë

6.Shija dhe ndjesia: E ëmbël, e ngrohtë, e thatë

7.Veprimi: Anti-inflamator, antimikrobial, analgjezik, antioksidant, agjent hipoglicemik, vazodilatator periferik .

8.Veprimi antimikrobial: antibakterial, antifungal, antiviral

9.Indikimet: Keiliti angular, stomatiti aftoz, herpes, gjuha me qime, kandidiazis, infeksion, antipllakë, karies, nxitës i shijes, halitosis, glosit.

10.Siguria në përdorim: I sigurtë kur përdoret sic duhet, kujdes tek ato gratë shtatzana dhe gjatë laktacionit

11.Përdorimi kulinar: $P O$

12.Përgatitja dhe dozimi: Çaj (gjysëm lugë çaji me pluhur kanelle në $240 \mathrm{ml}$ ujë të vluar),

Aplikim topikal (lulet e thërrmuara të lagura me salivë apo ujë), Tinkturë (PO; raporti $1: 5$ ose $1: 5$ në $70 \%$ etanol)

13.Kombinimi me: kalendula, karafil, stivia, trumzë, lëkurë portokalli. 
Xhuena Amuli, Valbona Disha

B. STIVIA (2)

1.Emri i përbashkët: Gjethe sheqeri, gjethe e ëmbël

2.Emri botanik: Stevia Rebaudiana

3.Familja e bimës: Asteraceae

4.Pjesa e përdorur: Gjethja

5.Gjendja e përdorur: E tharë

6.Shija dhe ndjesia: E ëmbël, e ftohtë

7.Veprimi: Antikariogjenik, antimikrobial, antipllakë, nutricional

8.Veprimi antimikrobial: Antibakterial

9.Indikimet: karies, diabet, erozion smalti, lëndë ëmbëlsuese.

10:Siguria në përdorim: konsiderohet i sigurtë

11.Përdorimet Kulinare: $P O$

12.Përgatitja dhe dozimi: Çaj (1lugë çaji në një filxhan me ujë, pasi ngrihet në kuba, mund të përdoret si ëmbëlsues për pije të ndryshme. Tinkturë (në raportin 1:5,60\% etanol)

13.Kombinimi me: më shumë me bimë që përdoren për kujdesin e shëndetit oral, në pije dhe ushqime të pjekura.

\section{PROPOLISI (2)}

1.Emri i përbashkët: ngjitës blete,balsam propolisi, rezinë propolisi, penicilina ruse.

2.Emri botanik: nuk aplikohet

3.Familja e bimës: nuk aplikohet

4.Pjesa e përdorur: Saliva e bletës, me dyll dhe eksudate të mbledhura nga burime botanike përdoren për të veshur hojet e bletës, me qëllim mbrojtjen e tyre nga lagështira, invaduesit dhe faktorët e jashtëm dëmtues 


\section{Gjendja e përdorur: I tharë}

6.Shija dhe ndjesia: e ngrohtë

7.Veprimi: antiinflamator, antimikrobial, antioksidant, kariostatik, imunostimulator

8.Veprimi antimikrobial: antibakterial, antifungal, antiviral

9.Indikimet: abces, shërimi i plagëve të ekstraksionit, karies, sinusit, kandidiazis, glositis, stomatit, karies, dhimbje, perikoronaritis.

10:Siguria në përdorim: në përgjithësi konsiderohet i sigurtë, kujdes tek pacientët me histori alergjie ndaj shpimit të bletës dhe poleneve.

\section{Përdorimet kulinare: JO}

12.Përgatitja dhe dozimi: Aplikim topikal (rezina e tharë vendoset në zonën e inflamuar) tinkturë (raporti 1:5 me 100\% etanol)

13.Kombinimi me: kalendula, kanellë, karafil, kripë, sherbelë, lule limoni, stevia, trumzë, rozmarinë.

\section{LËKURA E PORTOKALLIT: (2)}

1.Emri i përbashkët: portokall i ëmbël, portokall, portokallet e mesdheut

2.Emri botanik: citrus sinensis

3.Familja e bimës: rutaceae

4.Pjesa e përdorur: 1ëkura

5.Gjendja e përdorur: e tharë ose e njomë

6.Shija dhe ndjesia: e hidhur, e ëmbël, freskuese

7.Veprimi: anti-inflamator, antimikrobial, antioksidant, antitumoral

8.Veprimi antimikrobial: antibakterial, antifungal, antiviral

9.Indikimet: kandidiazis, glossitis, sëmundje gingivale, diabet, karies, inflamacion, periodontitis. 
Xhuena Amuli, Valbona Disha

10:Siguria në përdorim: Mund të afektojë përthithjen e disa medikamenteve, aplikimi direkt i vajërave esencial mund të japë fotosensitivitet.

\section{Përdorimet kulinare: $P O$}

12.Përgatitja dhe dozimi: Çaj(gjysëm luge çaji me lëkurë portokalli në $240 \mathrm{ml}$ ujë të vluar) tinkturë (raport 1:5 me 70\% etanol) vaj esencial (aplikim topikal)

13.Kombinimi me: lule balsam blete, karafil, kripë, stevia, kanellë, kopër.

\section{REZULTATE}

Nga studimet e marra në shqyrtim, rezultoi se:

$\checkmark$ Pastat, të cilat kanë në përbërjen e tyre elemente bimore, ku ndër to është edhe bima e stivias, shfaqin efekte reduktuese në ngarkesën bakteriale në pllakë nga $29-85 \%$ dhe po ashtu edhe në indeksin e pllakës nga 47-70\%.

$\checkmark$ Lëkura e portokallit e përgatitur në formën e ekstraktit etanolik të nxehtë shfaq veti inhibuese të s.mutans dhe lactobacilit in vitro. (1)Efekte të ngjashme shfaqin edhe bimët e tjera kulinare: kanella dhe karafili të përgatitura po ashtu në forma të ngjashme. (4)

$\checkmark$ Provat laboratorike kanë treguar se Propolisi i përdorur në formën e shpërlarësit të gojës ndikon pozitivisht në shërimin e plagëve postekstraktive, po ashtu ka rol dezinfektues në kavitetet karioze pasi ato preparohen. (5)

Për të përftuar nga vetitë e përshkruara në literaturë të këtyre bimëve, nevojiten disa procedura të trajtimit të bimëve nga gjendja e papërpunuar në atë të përpunuar. Nëse mësohen raportet e sakta të përgatitjes dhe me ndihmën e një herbalisti, fare thjeshtë mund të përgatiten përzierje bimore të ndryshme për të arritur një rezultat të caktuar. 
Tabela 1. Paraqitja e studimeve të ndryshme në lidhje me aftësinë reduktuese të pllakës dentare të disa bimëve.

\begin{tabular}{|c|c|c|c|c|}
\hline Studimi & $\begin{array}{l}\text { Lëkura e portokal- } \\
\text { lit }\end{array}$ & Stivia & Kanella & Propolosi \\
\hline $\begin{array}{l}\text { Sapna B.Shetty, } \\
2015 \text { (1) }\end{array}$ & $\begin{array}{l}\text { Pengonte rritjen e } \\
\text { bakterieve në pllakën } \\
\text { dentare }\end{array}$ & - & - & - \\
\hline $\begin{array}{l}\text { Gianmaria Fa- } \\
\text { brizio Ferrazza- } \\
\text { no, 2016 (3) }\end{array}$ & - & $\begin{array}{l}\text { U1 indeksin } \\
\text { e pllakës nga } \\
47-70 \%\end{array}$ & - & - \\
\hline $\begin{array}{l}\text { Gamboa dhe } \\
\text { Chaves në vitin } \\
2012(6)\end{array}$ & - & $\begin{array}{l}\text { U1 indeksin } \\
\text { e pllakës nga } \\
57-82 \%\end{array}$ & - & - \\
\hline $\begin{array}{l}\text { Hanna Elga- } \\
\text { mily, 2019 (7) }\end{array}$ & - & - & $\begin{array}{l}\text { Frenojnë rritjen e } \\
\text { S.mutans dhe l.a- } \\
\text { cidophylis }\end{array}$ & - \\
\hline $\begin{array}{l}\text { Korns Wiwat- } \\
\text { tanarattanbut, } \\
2017 \text { (4) }\end{array}$ & - & - & $\begin{array}{l}\text { Antipllakë e fu- } \\
\text { qishme }\end{array}$ & - \\
\hline $\begin{array}{ll}\text { Carvalho dhe } \\
\text { Magro (5) }\end{array}$ & - & - & - & $\begin{array}{l}\text { Nxit shërimin e pla- } \\
\text { gës, anti-inflamator dhe } \\
\text { analgjezik }\end{array}$ \\
\hline
\end{tabular}

\section{DISKUTIME}

Rezultatet e studimeve dhe të dhënat nga literatura e shkruar janë mjaft premtuese përsa $\mathrm{i}$ përket përdorimit të bimëve në stomatologji. Me gjithë studimet e kryera ende nuk kemi në klinikat tona një produkt me bazë bimore që frenon kariesin.

Në studimet in vitro të paraqitura më lart, u përdorën metoda të veçanta laboratorike. Vlen të përmendet se mungesa e një instituti kërkimor të mirëfilltë në Shqipëri përbën kufizim.Studimi në lidhje më lëkurën e portokallit, na jep të dhëna mjaft pozitive përsa i përket efekteve që ky përbërës bimor jepte kundër bakterieve karies shkaktuese.

Në studime të tjera të kryera edhe lëkura e shegës ka treguar aktivitet frenues, madje më të lartë se lëkura e portokallit. (8) (1) Efektet anësore që mund të ketë aplikimi i këtyre bimëve përkundrejt rezultateve të dëshiruara që synojmë të arrijmë, le vend per diskutim. 
Xhuena Amuli, Valbona Disha

Në studim përmendet se propolisi mund të japë reaksione alergjike tek pacientët alergjik ndaj pickimit të bletës apo poleneve, studime të tjera kanë treguar që propolisi të jetë efikas në trajtimin e rinitit alergjik. (5)Duket se struktura dhe përbërja e këtij elementi ndryshon në zona gjeografike të ndryshme dhe në kohë të ndryshme të vitit.

Po ashtu përballja e propolisit me klorheksidinën si shpërlarës oral, lë vend për diskutim. Propolisi në formë xheli ka dhënë efekt pozitiv në këtë përdorim po ashtu. (5) Veprimi antim mikrobial, antiinflamator, biokompatabiliteti duket se lë pas klorheksidinën, e cila konsiderohet standardi i artë.

Studimet in vitro kanë rezultuar pozitive për shumicën e bimëve dhe efektet e tyre. Megjithatë duhet të kryhen teste të mëtejshme mbi këto bimë për të përcaktuar toksicitetin, efektet anësore, dozat dhe formën në të cilën do mund të ofrohet si medikament farmaceutik me efektin e dëshiruar. Në përdorimet e tyre si suplemente kulinare normalisht nuk është e nevojshme kryerja e këtyre testeve dhe përcaktimeve të mëtejshme.

\section{KONKLUZIONE}

Kariesi është një ndër sëmundjet infektive kronike më të përhapura në botë. Megjithë ndërhyrjet me fluorizimin e ujit apo kripës dhe ndryshimet e bëra në standardin e higjenës orale, kariesi vazhdon të mbetet një ndër problemet orale madhore. Për sa kohë ekziston kjo gjendje, duhet të inkurajohen studimet e mëtejshme në lidhje me kërkimin e alternativave të reja për kontrollin bakterial klinik. Në përfundim të këtij studimi u theksua rëndësia e herbalizmit dhe disa nga bimët të cilat paraqesin të dhëna premtuese për të ardhmen në lidhje me efektet antikariogjenike. Bimët e ndryshme kulinare apo të trajtuara si mbetje (lëkura e portokallit) treguan se kanë potencial në reduktimin e kariesit, potencial ky i cili duket se ka qenë aty i fshehur tek këto bimë për mijëra vite me rradhë. Në Shqipëri pavarësisht se mund të gjenden lehtë një pjesë e bimëve me efekte pozitive në kavitetin oral, mungesa e një instituti kërkimor përbën kufizim për këtë studim. 
HERBALIZMI DENTAR

\section{Referenca}

1. Sapna B.Shetty, Prabu Mahin Syed Ismail, Shaji Varghese, et.al . Antimicrobial effects of Citrus sinensis peel extracts against dental caries bacteria: An in vitro study. J Clin Exp Dent 2016;8 (1):e71 - e 77 .

2. Leslie M.Alexander, Linda A.Straub-Bruce Dental Herbalism Natural Therapies for the mouth . Rochester Vermont, Toronto Canda; Healing Arts Press ; 2014.

3. Gianmaria Fabrizio Ferrazzano, Tiziana Cantile, Brunella Alcidi, et.al . Is Stevia rebaudiana Bertoni a Non Cariogenic Sweetener? A Review. Molecules 2016 ; 21(1): 38 .

4. Amir Jalal Abbasi, Farnoush Mohammadi, Mohamad Bayat, et.al . Applications of Propolis in Dentistry: A Review. Ethiop J Health Sci 2018 ; 28(4) : 505-512 .

5. Magro FILHO O, de CARVALHO ACP. Application of propolis to dental sockets and skin wounds. The Journal of Nihon University School of Dentistry. 1990;32(1):4-13.

6. Fredy Gamboa, Margarita Chaves . Antimicrobial potential of extracts from Stevia rebaudiana leaves against bacteria of importance in dental caries. Acta Odontol Latinoam $2012 ; 25$ (2) : 171-5.

7. Hanaa Elgamily, Rehab Safy, Rabab Makharita . Influence of Medicinal Plant Extracts on the Growth of Oral Pathogens Streptococcus Mutans and Lactobacillus Acidophilus: An In-Vitro Study. Open Access Maced J Med Sci 2019 ; 7 (14) : 2328-2334.

8. Viral V Mehta, Gururaghavendran Rajesh, Ashwini Rao, Ramya Shenoy, Mithun Pai B H . Antimicrobial Efficacy of Punica granatum mesocarp, Nelumbo nucifera Leaf, Psidium guajava Leaf and Coffea Canephora Extract on Common Oral Pathogens: An In-vitro Study. J Clin Diagn Res 2014 ; 8 (7) : ZC65-8 .

9. E.Saira Siraj, K.Pushpanjali , B.S.Manoranjitha . Efficacy of stevioside sweetener on pH of plaque among young adult. Dent Res J (Isfahan) 2019 ; 16(2) : 104-109 .

10. Kornsit Wiwattanarattanabut, Suwan Choonharuangdej, Theeerathavaj Srithavaj . In Vitro Anti-Cariogenic Plaque Effects of Essential Oils Extracted from Culinary Herbs . J Clin Diagn Res 2017 ; 11 (9) : DC30-DC35 . 